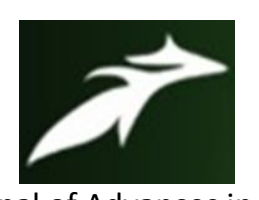

Astuti Verma et al, International Journal of Advances in Agricultural Science and Technology,

Vol.2 Issue. 2, February- 2014, pg. 85-93

ISSN: 2348-1358

\title{
Extraction of Pear (Pyrus Pyrifolia cv. Gola) Fruit Pulp and its Storage Stability
}

\author{
Astuti Verma; Archana Kushwaha* \\ Department of Foods and Nutrition, College of Home Science, G.B. Pant Agriculture University and \\ Technology, Pantnagar -263145 (U. S. Nagar, Uttarakhand) \\ *Corresponding Author \\ DOI: 10.47856/ijaast.2014.v02i2.001
}

Submitted on: 15-12-2013

Accepted on: 24-02-2014

\begin{abstract}
A research was carried out to investigate the effect of storage on pulp, extracted from pear fruit, persevered with potassium metabisulphite (KMS), packed in glass bottles and stored at low temperature $\left(6 \pm 1^{\circ} \mathrm{C}\right)$ for 180 days. Pulp recovery from pear fruit was $54.8 \%$. Physico-chemical parameters of fresh pear pulp viz. pH, TSS, titrable acidity, sugar/acid ratio and ascorbic acid were tended to be $3.93,12.67^{\circ} \mathrm{Brix}, 0.38 \%, 33.51 \%$ and $5.25 \mathrm{mg} / 100 \mathrm{~g}$, respectively which were changed to 3.7, $13.67{ }^{\circ}$ Brix, $0.46 \%, 30.2 \%$ and $4.32 \mathrm{mg} / 100 \mathrm{~g}$, respectively. Reduction in $\mathrm{pH}$ (3.93 to 3.7) was significant ( $p<0.05)$. No fungal (yeast and mould) growth was observed during storage of 180 days. It was found that pasteurized pear pulp could be stored for extended period of time without any major changes in chemical composition and could be used for preparation of Jam in any season.
\end{abstract}

Keywords: Pyrus pyrifolia, Gola pear, storage stability, pear fruit pulp, physico-chemical parameters, storage stability.

\section{Introduction}

Fruits and vegetables are important constituents of the diet and provide significant quantities of nutrients, especially vitamins, minerals, sugars, and fiber. Daily consumption of fruits and vegetables reduce the risk of cancer, heart disease, premature aging, stress, and fatigue primarily due to the integrated action of oxygen radical scavengers such as B-carotene and ascorbic acid plus calcium and dietary fiber. Most of the fruits and vegetables produced in India are still consumed fresh except for a very small (1.5\%) quantity going into the manufacturing of pickles, drinks, fruit jelly, candy, juices, jam and dried fruits. Due to the perishable nature of the fruits and vegetables, they require immediate processing to avoid post-harvest losses (20-25\%) (Bhardwaj and Pandey, 2011).

Fruit processing and preservation play an important role in the conservation and better utilization of fruits in order to avoid the glut during season and utilize the surplus during the off season. It ensures fair returns to the growers to improve their economic 


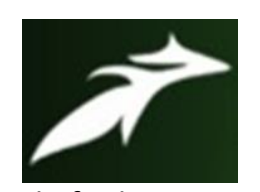

Astuti Verma et al, International Journal of Advances in Agricultural Science and Technology, Vol.2 Issue. 2, February- 2014, pg. 85-93

ISSN: 2348-1358

condition and helps to mitigate the problem of under employment during off seasons in the agricultural sectors. The main objective of fruit processing is to supply wholesome, safe, nutritious and acceptable food to consumers throughout the year (www.dsir.gov.in, 30.10.2013). Processing improves the viability, profitability and sustainability of fruit production systems by increasing farm incomes, and generating rural employment and foreign exchange (Rolle, 2006).

Pear fruit (Pyrus pyrifolia) is Asiatic pear belonging to the family Rosaceae. It is merited with number of desirable attributes like hardiness, yielding without receiving external agro-inputs, processing potential, and most important its nutritional and phytochemical properties. A large number of pear varieties are grown in Uttarakhand. Early varieties of pear include Thumb pear (Chusni), Shinsui, Kosui and Shinseiki. Mid-season varieties include Pathernakh, Gola, Hosui, Pant Pear-18, Victoria, Conference, Flemish Beauty and LeConte. Late season varieties include Winter Nails, Beurre Hardy, Jargnel, Bartlett, Max Red Bartlett, 31 Babbugosa, Pant 32 Pear-3, Pant pear-17 and Nijisseiki (Kundu et al. 2013).

'Gola' variety of pear is a highly seasonal with an average yield of $150 \mathrm{~kg}$ fruits per tree. Fruits are large, round, greenish-yellow with prominent dots. Pulp is somewhat gritty, sweet with plenty of juice. It is a climacteric fruit and ripens mid to late July. Due to hardy nature, fruits can be stored well at room temperature for 20-25 days (Kundu et al. 2013). The acceptability and utilization of pear fruits can be increased by processing it into the most economical and useful value added products.

The semi-processed fruit products are manufactured in order to be delivered to industry processing plant for manufacture into consumer oriented finished products such as jams, jellies, syrups, fruits in syrup, etc. The categories of semi-processed fruits as defined by Lozano (2006) are fruit pulp, purees and juices.

Fruit pulp is obtained by mechanical treatment (or, less often, by thermal treatment) of fruit followed by their preservation. Either, whole fruit, halves or big pieces are used which enables easy identification of the species. Pulps can be classified as boiled or non boiled (raw). Fruit purees are obtained by thermal and mechanical treatment operations by which all non edible parts (cores, peels, etc.) are removed. It is also classified as boiled and 


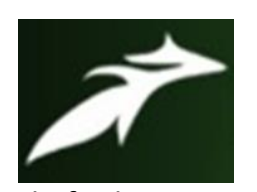

Astuti Verma et al, International Journal of Advances in Agricultural Science and Technology,

Vol.2 Issue. 2, February- 2014, pg. 85-93

ISSN: 2348-1358

non boiled. Semi-processed juices are the products obtained by cold pressure or eventually by other treatments (diffusion, extraction, etc.) followed by the preservation.

\section{Materials \& Methods}

Mature pear (Pyrus pyrifolia cv. Gola) fruits were harvested at 140 days after full bloom, and procured from Horticulture Research Centre, G.B.P.U.A. \&T., Pantnagar (Uttarakhand, India). Potassium metabisulphite (KMS) was purchased from local market. Experiments were conducted at Departments of Foods \& Nutrition, G.B.P.U.A. \&T., Pantnagar.

\section{Fruit Pulp Extraction and its preservation}

Fruit pulping and its preservation were done by standard method given by Lal et al. (2009). Steps for pulp extraction are shown in Figure 1 and 2. Fruits were washed thoroughly with fresh running tap water to remove any adhering dust and dirt followed by wiping with muslin cloth. Leaves, stalks and other undesirable portions were removed. Fruits were subjected to peeling, coring and dicing with the help of sharp stainless steel knife followed by dipping in 0.2 per cent citric acid solution to avoid browning (Shakir et al., 2009). Pulping of fruit was done with the help of grinder. Pulp was pasteurized up to boil in open pan and preserved in 1000 ppm SO $\mathrm{SO}_{2}$ (Sharma, 2010) by adding KMS. Pulp was filled in airtight presterilized glass bottles and kept in dark at low temperature $\left(6 \pm 1^{\circ} \mathrm{C}\right)$, maintained in a refrigerator. Storage stability of pectin extract was examined up to 180 days at the interval of 30 days.

\section{Physico-chemical analysis of Pear Pulp}

Fresh and stored pulp was analyzed for TSS, titrable acidity, ascorbic acid and sugar to acid ratio by following the method described by Ranganna (1986). Whereas $\mathrm{pH}$ of pulp was measured according to the method of AOAC (1995). Pear pulp was analyzed for yeast and mould count by using standard plate count method described by Koburger and Marth (1984). 


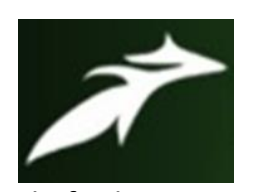

Astuti Verma et al, International Journal of Advances in Agricultural Science and Technology,

Vol.2 Issue. 2, February- 2014, pg. 85-93

ISSN: 2348-1358

\section{Statistical Analysis}

Results were analyzed statistically for their interpretation, using completely randomized design (CRD) to find out the significant changes during storage (Snedecor and Cochran, 1967).

\section{Result \& Discussion}

Pulp recovery from pear fruit was 54.8 per cent. Physico-chemical parameters of fresh pear pulp viz. $\mathrm{pH}$, TSS, titrable acidity, sugar/acid ratio and ascorbic acid were tend to be $3.93,12.67^{\circ}$ Brix, 0.38 per cent, 33.51 per cent and $5.25 \mathrm{mg} / 100 \mathrm{~g}$, respectively. The values of physicochemical parameters of fresh \& stored pear pulp are presented in Table 1.

\section{Physicochemical changes in pear pulp during storage}

pH

A significant reduction in $\mathrm{pH}$ (3.93 to 3.7) was observed during storage of 180 days. The $\mathrm{pH}$ values of pulp after storage period of 30, 60,120 and 150 days were 3.96, 3.89, 3.84, 3.81 and 3.8, respectively. Result on decreasing $\mathrm{pH}$ of pulp during storage was in agreement with the finding of Durrani et al. (2010) for apple pulp and Akhtar et al. (2010) for mango pulp. Similar trend was observed by Jain et al. (2011) for papaya and guava pulp. This decrease in $\mathrm{pH}$ may be due to the formation of free acids and pectin hydrolysis (Imran et al., 2000).

\section{Total Soluble Solids (TSS)}

TSS of pulp was slightly increased from 12.67 to $13.67^{\circ}$ Brix after 180 days of storage. The TSS of pulp after storage period of 30, 60, 90, 120 and 150 days were 12.67, 13.0, 13.0, 13.33 and $13.33{ }^{\circ}$ Brix, respectively. However, these changes in TSS were insignificant. The results were in similar trend as reported by Durrani et al. (2010) for apple pulp; Akhtar et al. (2010) for mango pulp and Jain et al. (2011) for papaya and guava pulp. Shah et al. (1975) mentioned that increase in soluble content of the product may be due to the solubilization of fruit constituents during storage.

\section{Titrable acidity}

No change in titrable acidity ( 0.38 percent) was found after 30 days storage. A slight insignificant increase was observed after storage of 60 (0.42\%), $90(0.42 \%), 120(0.42 \%)$, 


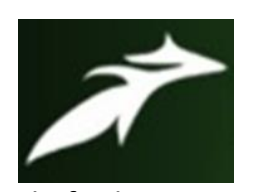

Astuti Verma et al, International Journal of Advances in Agricultural Science and Technology, Vol.2 Issue. 2, February- 2014, pg. 85-93

ISSN: 2348-1358

$150(0.46 \%)$ and 180 days $(0.46 \%)$. The results for titrable acidity in present study are in accordance with the results reported by Durrani et al. (2010) in apple pulp, Akhtar et al. (2010) in mango pulp and Jain et al. (2011) in papaya and guava pulp.

\section{Sugar/acid ratio}

Sugar/acid ratio in fresh pulp (33.51\%) was slightly decreased to $30.2 \%$ after storage of 180 days. Sugar/ acid ratios were 36.6, 31.53, 31.53, 32.19 and $29.54 \%$ after storage of 30, 60, 90, 120 and 150 days, respectively. Although, both TSS and acidity were slightly increased during storage but the decreasing trend of results reflect that the increase in acidity was more in comparison to TSS. Similar trend was observed by Durrani et al. (2010) during storage of apple pulp.

\section{Ascorbic acid}

Data in Table 1 reflect that ascorbic acid content in fresh pear fruit pulp was $5.25 \%$ which was insignificantly reduced (5.25 to $4.32 \%$ ) after 180 days of storage. These results are in agreement with the finding of Durrani et al. (2010) in apple pulp and Jain et al. (2011) in papaya and guava pulp, who recorded a decrease in ascorbic acid content as storage period advanced.

\section{Changes in microbiological characteristics of stored pulp}

No fungal (yeast and mould) growth was observed up to storage period of 180 days. It indicates that pear fruit pulp could be used safely up to 180 days.

\section{Conclusion:}

The study concluded that, except $\mathrm{pH}$, storage period had a non-significant effect on physico-chemical and microbiological attributes of chemically preserved pear pulp which reflects that pear fruit pulp could be used for jam preparation up to 6 months without significant change in its quality. Decreasing $\mathrm{pH}$ towards advancement of storage time is also good indication as it contributes in creating an unfavorable condition for microbial growth.

\section{Acknowledgement}

Ms. Astuti Verma is thankful to UGC, New Delhi for the Senior Research Fellowship to undertake the study. 


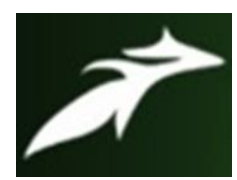

Astuti Verma et al, International Journal of Advances in Agricultural Science and Technology, Vol.2 Issue. 2, February- 2014, pg. 85-93

ISSN: 2348-1358

\section{References}

[1]. A.O.A.C. 1995. Official Method of Analysis, The Association of Official Analytical Chemists, Washington.

[2]. Akhtar, S.; Riaz, M.; Ahmad, A. and Nisar, A. 2010. Physico-chemical, microbiological and sensory stability of chemically preserved mango pulp. Pak. J. bot. 42(2): 853-862.

[3]. Bhardwaj, R.L. and Pandey, S.2011. Juice Blends - A Way of Utilization of UnderUtilized Fruits, Vegetables, and Spices: A Review. Critical Reviews in Food Science and Nutrition. 51:563-570.

[4]. Durrani,Y.: Ayub, M.: Muhammad, A. and Ali, A. 2010. Physico-chemical response of apple pulp to chemical preservatives and antioxidant during storage. Int. J. Food Saf. 12:20-28.

[5]. Imran, A.; Khan, R. and Ayub, M. 2000. Effect of added sugar at various concentrations on the storage stability of guava pulp. Sarhad J. Agric. 16(1): 89-93.

[6]. Jain, P.K.; Jain, P. and Nema, P.K. 2011.Quality of guava and papaya fruit pulp as influenced by blending ratio and storage period. Am. J. Food Technol.6 (6):507-512 .

[7]. Koburger, J.A. and Marth, E.H.1984. Yeast and Molds. In: Speck, M.L. ed. Compendium of methods for the microbiological examination of foods. $2^{\text {nd }}$ ed. Washington, American Public Health Association.pp.197-201.

[8]. Kundu M, Joshi R, Rai PN, Bist LD (2013) Effect of plant bio-regulators on fruit growth, quality and productivity of pear [Pyrus pyrifolia (Brum.) Nakai] cv Gola under Tarai condition. J Appl Hortic 15(2):106-109.

[9]. Lal, G.; Siddappaaa, G.S. and Tondon, G.L. 2009. Preservation of fruits and vegetables. $4^{\text {th }}$ ed. Indian Council of Agricultural Research, New Delhi. pp.156-189.

[10].Lozano, J.E. 2006. Fruit Manufacturing: scientific basis, engineering properties, and deteriorative reactions of technological importance. Springer Science and business media, LLC, 233 spring street, New York. pp. $17 \& 18$.

[11].Rolle, R.S. 2006. Processing of fruits and vegetables for reducing postharvest losses and adding value. In: Rolle, R.S. ed. Postharvest Management of Fruits and Vegetables in the Asia-Pacific Region. Tokyo, APO. pp. 32-42.

[12].Shah, W.H.; Sufi, N.A. and Zafar, S.I. 1975. Studies on the storage stability of guava fruit juice. Pak. J. Sci. Ind. Res. 18(3-4): 179-183.

[13].Shakir, I.; Hussain, I.; Zeb, A. and Durrani, Y. 2009. Sensory evaluation and microbial analysis of apple and pear mixed fruit jam prepared from varieties grown in Azad Jammu and Kashmir. World J. Dairy Food Sci. 4 (2): 201-204.

[14].Sharma, S.K. 2010. Postharvest management and processing of fruits and vegetables. New India Publishing Agency, New Delhi.pp132-147.

[15].Snedecor, G.W. and Cochran, W.G. 1967. Statistical methods. 6th ed. Calcutta, Oxford \& IBH Pvt. Co. Ltd.

[16].www.dsir.gov.in Fruits \& Vegetables Sector: An Overview. 30.10.2013 


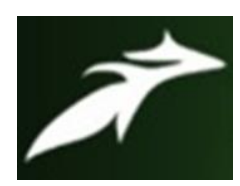

Astuti Verma et al, International Journal of Advances in Agricultural Science and Technology,

Vol.2 Issue. 2, February- 2014, pg. 85-93

ISSN: 2348-1358

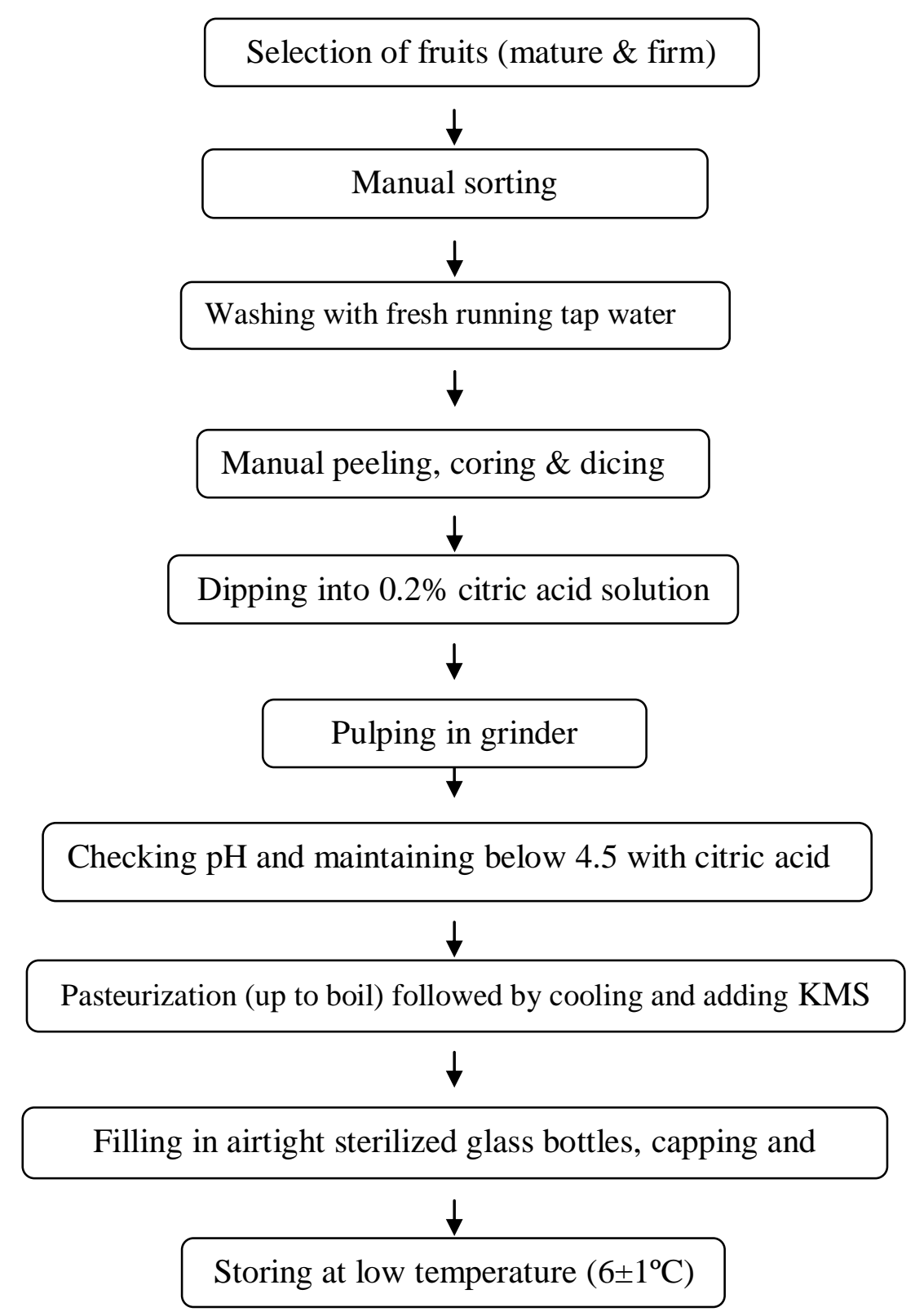

Fig 1. Flow chart for fruit pulping and its preservation 


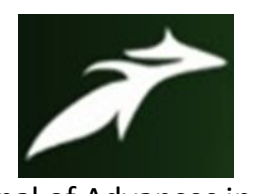

Astuti Verma et al, International Journal of Advances in Agricultural Science and Technology, Vol.2 Issue. 2, February- 2014, pg. 85-93

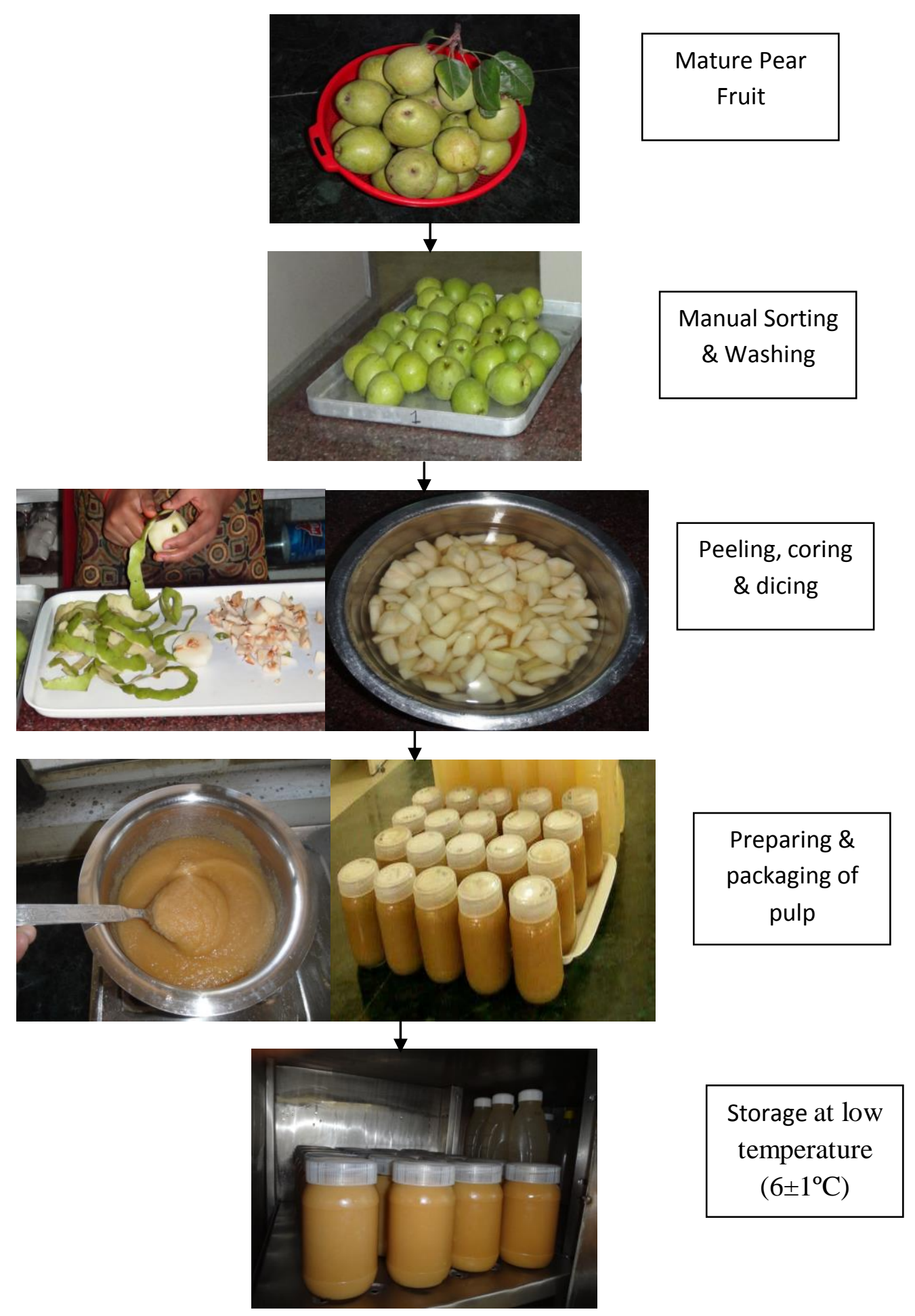

Fig 2. Overview of fruit pulping and its preservation 


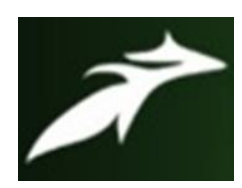

Astuti Verma et al, International Journal of Advances in Agricultural Science and Technology,

Vol.2 Issue. 2, February- 2014, pg. 85-93

ISSN: 2348-1358

Table 1 Effect of storage on physicochemical and microbiological characteristics of preserved pear fruit pulp ${ }^{\#}$

\begin{tabular}{|c|c|c|c|c|c|c|}
\hline \multirow{2}{*}{$\begin{array}{c}\text { Storage } \\
\text { time (days) }\end{array}$} & $\mathrm{pH}$ & TSS $\left({ }^{\circ}\right.$ Brix $)$ & $\begin{array}{c}\text { Titrable } \\
\text { acidity } \\
\text { (per cent) }\end{array}$ & $\begin{array}{c}\text { Sugar/acid } \\
\text { ratio }\end{array}$ & $\begin{array}{c}\text { Ascorbic } \\
\text { acid } \\
(\mathrm{mg} / 100 \mathrm{~g})\end{array}$ & $\begin{array}{c}\text { Yeast \& } \\
\text { mould } \\
\text { count }\end{array}$ \\
\hline $\begin{array}{c}\text { Initial } \\
\text { (fresh pulp) }\end{array}$ & $3.93 \pm 0.01^{\mathrm{b}}$ & $12.67 \pm 0.58$ & $0.38 \pm 6.8 \mathrm{E}-17$ & $33.51 \pm 1.53$ & $4.94 \pm 0.53$ & Absent \\
\hline 30 & $3.96 \pm 5.4 \mathrm{E}-16^{\mathrm{a}}$ & $12.67 \pm 0.58$ & $0.38 \pm 0.13$ & $36.6 \pm 14.02$ & $4.92 \pm 0.66$ & Absent \\
\hline 60 & $3.89 \pm 0.0^{\mathrm{c}}$ & $13 \pm 0.0$ & $0.42 \pm 0.07$ & $31.53 \pm 4.96$ & $4.93 \pm 0.53$ & Absent \\
\hline 90 & $3.84 \pm 0.01^{\mathrm{d}}$ & $13 \pm 0.0$ & $0.42 \pm 0.07$ & $31.53 \pm 4.96$ & $4.69 \pm 0.0$ & Absent \\
\hline 120 & $3.81 \pm 0^{\mathrm{e}}$ & $13.33 \pm 0.58$ & $0.42 \pm 0.07$ & $32.19 \pm 3.82$ & $4.6 \pm 0.5$ & Absent \\
\hline 150 & $3.8 \pm 0.01^{\mathrm{f}}$ & $13.33 \pm 0.58$ & $0.46 \pm 0.07$ & $29.54 \pm 6.49$ & $4.55 \pm 0.0$ & Absent \\
\hline 180 & $3.7 \pm 0.01^{\mathrm{g}}$ & $13.67 \pm 0.58$ & $0.46 \pm 0.07$ & $30.2 \pm 6.0$ & $4.32 \pm 0.53$ & Absent \\
\hline F value & $1242.61^{*}$ & 1.733 & 0.583 & 0.267 & 0.78 & - \\
\hline SEM \pm & 0.0025 & 0.28 & 0.04 & 4.03 & 0.27 & - \\
\hline $\begin{array}{c}\text { CD value } \\
(p<0.05)\end{array}$ & 0.008 & $\mathrm{NS}$ & $\mathrm{NS}$ & $\mathrm{NS}$ & $\mathrm{NS}$ & - \\
\hline
\end{tabular}

${ }^{\#}$ Mean \pm standard deviation $(n=3)$; $*$ Significant difference; NS = Non significant

Values followed by different superscripts in a column are significantly $(p<0.05)$ different from each other 